\title{
The post-pericardiotomy syndrome causing cardiac tamponade and pleural effusion in a patient that underwent mitral valve replacement
}

\author{
Kazim Ergunes, Hasan Iner, Ismail Yurekli, Orhan Gokalp, Ufuk Yetkin, Ali Gurbuz \\ From World Society of Cardiothoracic Surgeons 25th Anniversary Congress, Edinburgh \\ Edinburgh, UK. 19-22 September 2015
}

\section{Background/Introduction}

The post-pericardiotomy syndrome (PPS) is an important complication following cardiac surgery.

\section{Aims/Objectives}

We presented a patient with pericardial tamponade and pleural effusion that underwent mitral valve replacement.

\section{Method}

A 45-year-old man was hospitalized in our clinic on March 26, 2015. He had chest pain, dyspnea, and easy fatigability. He underwent mitral valve replacement one month ago. The diagnosis of pericardial effusion was confirmed by echocardiogram. The chest X-ray showed left pleural effusion.

\section{Results}

Subxiphoid pericardial drainage and right thoracic pleural drainage were performed under local anesthesia. Pericardial serous fluid of $400 \mathrm{ml}$ was drained. The right pleural serous fluid of $500 \mathrm{ml}$ was drained. A subxiphoid pericardial and right thoracic drainage tube were inserted during surgery and removed after 4 days. No microorganism was cultivated from pericardial and pleural fluids. After hospital discharge, patient was followed with physical examination, echocardiography, and chest $\mathrm{X}$-ray.

\section{Discussion/Conclusion}

Subxiphoid pericardial window under local anesthesia is an important surgical method for pericardial drainage in patients with pericardial effusion due to postpericardiotomy syndrome.

\section{Consent}

Written informed consent was obtained from the patient for publication of this abstract and any accompanying images. A copy of the written consent is available for review by the Editor of this journal.

Published: 16 December 2015

\section{doi:10.1186/1749-8090-10-S1-A112}

Cite this article as: Ergunes et al:: The post-pericardiotomy syndrome causing cardiac tamponade and pleural effusion in a patient that underwent mitral valve replacement. Journal of Cardiothoracic Surgery 2015 10(Suppl 1):A112.
Submit your next manuscript to BioMed Central and take full advantage of:

- Convenient online submission

- Thorough peer review

- No space constraints or color figure charges

- Immediate publication on acceptance

- Inclusion in PubMed, CAS, Scopus and Google Scholar

- Research which is freely available for redistribution
() Biomed Central 